\title{
A Bibliography of English Language Commentaries on the Philosophy of Edith Stein
}

\author{
John Haydn Gurmin
}

In recent years a great deal of secondary literature has been published in relation to the works of Edith Stein. The literature spans a number of languages and covers many disciplines of study. ${ }^{1}$ What is undertaken here is to make available a bibliography of secondary literature in English - this bibliography focuses on publications that emphasise the philosophical nature of Stein's writings in particular. Sarah Borden and Kevin Jones have compiled a more complete and thorough account of the extant secondary literature (spanning a variety of languages) on the writings of Stein which is available online. ${ }^{2}$ What we find below is taken in principle from Borden and Jones' compilation. However, there have been a number of additions made to the bibliography; (i) in terms of articles and books which have just recently been published, such as Mette Lebech's On the Problem of Dignity (2009) and (ii) those that are forthcoming, such as Sarah Borden's, Thine Own Self: Individuality in Edith Stein's Later Writings (late 2009) etc. Further additions have been made to take account of the following important philosophical commentaries on the works of Stein: Marianne Sawicki's article - 'Making-Up-Husserl's Mind about Constitution' (2007), Evan Thompson's book Mind in Life: Biology, Phenomenology, and the Sciences (2007), and Wilk's article, 'On Human Being: A Dispute between Edith Stein and Martin Heidegger' (2007).

It is evident from this bibliography (and in particular from the date of publications) that Stein's works are valuable resources for modern thinkers. In terms of promoting the philosophy of Edith Stein further - it is our desire to establish an Association for the Promotion and Study of the Philosophy of Edith Stein. Anyone wishing to receive further information with regard to this Association can do so by contacting mette.lebech@nuim.ie or john.h.gurmin@nuim.ie.

\section{Ales Bello, Angela}

"Edith Stein, Phenomenology, the State and Religious Commitment" in Analecta Husserliana: The Yearbook of Phenomenological Research Vol. LXXX: Phenomenology World-Wide, ed. Anna-Teresa Tymieniecka (Dordrecht: Kluwer Academic Pub, 2002), 648-656

\footnotetext{
${ }^{1}$ Stein's writings have influenced a great array of disciplines including feminism, political philosophy, psychology, theology, and not least philosophy.

2 See http://www.baltimorecarmel.org/ - go to 'carmelite saints' and select Edith Stein. For secondary literature A-C consult: http:/ / www.baltimorecarmel.org/saints/Stein/borden\%20bibliography\%20a-c.htm, D-G consult: http://www.baltimorecarmel.org/saints/Stein/borden\%20bibliography\%20d-g.htm ... H-L consult: http://www.baltimorecarmel.org/saints/Stein/borden\%20bibliography\%20h-l.htm $\quad$.. M-R consult: http://www.baltimorecarmel.org/saints/Stein/borden $\% 20$ bibliography $\% 20 \mathrm{~m}$-r.htm ... and S-Z consult: http://www.baltimorecarmel.org/saints/Stein/borden\%20bibliography\%20s-z.htm ... Accessed $5 / 05 / 2009$. This website was compiled by Sarah Borden and Kevin Jones and was last updated in December 2008. Anyone noticing omissions in the secondary literature on the Baltimore website are welcome to contact the adminstrators with the relevant bibliographical details.
}

(C) - John Haydn Gurmin, 'A Bibliography of English Language Commentaries on the Philosophy of Edith Stein', in Maynooth Philosophical Papers, Issue 5 (2008), ed. by Simon Nolan (Maynooth: Department of Philosophy, National University of Ireland, Maynooth, 2009), pp. 56-74. 
"Edith Stein's Anthropology: the Degrees of the Spirit" at http://www.stoqatpul.org/lat/materials/research07_alesbello.pdf

"Edith Stein's Contribution to Phenomenology" in Analecta Husserliana: The Yearbook of Phenomenological Research Vol LXXX: Phenomenology World-Wide, ed. Anna-Teresa Tymieniecka (Dordrecht: Kluwer Academic Pub, 2002), 232-240

"Edmund Husserl and Edith Stein: the question of the human subject" (trans. Antonio Calcagno) in American Catholic Philosophical Quarterly, 82:1 (Winter 2008), 143-160.

"From empathy to solidarity. Intersubjective connections according to Edith Stein" in Life. In the Glory of its Radiating Manifestations [Analecta Husserliana 48](Boston: Kluwer, 1996), 367-375.

"Ontology, metaphysics, and life in Edith Stein" in Contemplating Edith Stein ed. J.A. Berkman (Notre Dame, Ind: University of Notre Dame Press, 2006), 271-282.

"The Study of the Soul Between Psychology and Phenomenology in Edith Stein" in The Philosophy of Edith Stein: The Eighteenth Annual Symposium of the Simon Silverman Phenomenology Center (Pittsburgh: Silverman Institute for Phenomenology at Duquesne University, 2001), 3-17.

\section{Allen, Prudence}

"Edith Stein: The Human Person as Male and Female" in Allen's Images of the Human: The Philosopby of the Human Person in a Religious Context (Chicago: Loyola Press, 1995), 399-432.

"Metaphysics of Form, Matter, and Gender" in Lonergan Workshop, Volume 12 ed. Fred Lawrence (Boston, MA: Boston College, 1996), 1-25.

"The Passion of Saint Edith Stein" in Fides Quaerens Intellectum, 1:2 (Winter 2001), 201-250.

Review of Stein's Woman, in Review of Metaphysics, 52:1 (1998), 180181.

"Sex and Gender Differentiation in Hildegard of Bingen and Edith Stein" in Communio, 20 (Summer 1993), 389-414.

\section{Allers, Rudolf}

"On Darkness, Silence, and the Nought" in Thomist, 9 (1946), 515-572. 
Review of Edith Steins Werke II in New Scholasticism, 26 (1952), 480485.

\section{Andrews, Michael F.}

Contributions to the Phenomenology of Empathy: Edmund Husserl, Edith Stein and Emmanuel Levinas (Ph.D. dissertation, Philosophy, Villanova University, 2002).

"Faith Seeking Understanding: The Impossible Intentions of Edith Stein" in The Experience of God: A Postmodern Response, ed. Kevin Hart \& Barbara Wall (Bronx, NY: Fordham University Press, 2005).

Religion without Why: Edith Stein and Martin Heidegger on the Overcoming of Metaphysics, with Particular Reference to Angelus Silesius and Denys the Aeropagite" in Analecta Husserliana: The Yearbook of Phenomenological Research, Volume LXXXIX: Logos of Phenomenology and Phenomenology of the Logos, Book Two, ed. Anna-Teresa Tymieniecka (Dordrecht: Springer, 2006), $399-427$ “

\section{Anselm Mary [Madden]}

Edith Stein and the education of women: Augustinian themes (Doctoral dissertation, St. Louis University, 1962).

"Philosophy and the Religious Woman: Edith Stein" in Philosophy in a Technological Culture [Proceedings of the Workshop on Philosophy in a Technological Culture, June 13-24, 1963] ed. G.F. McLean (Washington, DC: Catholic University of America Press, 1964).

\section{Astell, Ann W.}

"Saintly mimesis, contagion, and empathy in the thought of Rene Girard, Edith Stein, and Simone Weil" in Shofar: an interdisciplinary journal of Jewish studies, 22:2 (Winter 2004), 116-131.

"Biblical images of God and the reader's 'I' as Imago Dei: the contribution of Edith Stein" in Interpretation, 59:4 (O 2005), 382-3

\section{Balzer, Carmen}

"The Empathy Problem in Edith Stein" in Husserlian Phenomenology in a New Key, 2 [Analecta Husserliana 35](Dordrecht: Reidel, 1991), 271-278.

"Hermeneutics of the Mystical Phenomenon in Edith Stein" in Analecta Husserliana: The Yearbook of Phenomenological Research, 
Volume LXXXIX: Logos of Phenomenology and Phenomenology of the

Logos, Book Two, 429-448

\section{Barnes, Brian Glen}

Versions of empathy: comparing the intersubjectivities of Edith Stein and Jean-Paul Sartre (M.A thesis, University of Louisville, 1997).

\section{Baseheart, Mary Catharine}

"Edith Stein's Philosophy of Community" in The Personalist Forum (Supplement), 8:1 (1993), 163-173.

"Edith Stein's Phenomenology of the State" in Reinterpreting the Political: Continental Philosophy and Political Theory ed. Lenore Langsdorf (Albany, NY: SUNY Press, 1998), 51-63.

"Edith Stein's Philosophy of the Person" in Edith Stein Symposium [Carmelite Studies 4] ed. John Sullivan (Washington DC: ICS Publications, 1987), 34-49.

"Edith Stein's Philosophy of Woman and Women's Education" in Hypatia. A Journal of Feminist Philosophy, 4:1 (1989), 267-279. Also in Hypatia's Daughters (Bloomington, IN: Indiana University Press, 1996).

The encounter of Husserl's phenomenology and the philosophy of St. Thomas in selected writings of Edith Stein (Doctoral dissertation, Philosophy, University of Notre Dame, 1960).

"Infinity in Edith Stein's Endliches und Ewiges Sein" in Proceedings of the American Catholic Philosophical Association, 55 (1981), 126- 134.

"The Manner is Contemporary" in America, 109 (August 31, 1963), 214-215.

"On Educating Women: The Relevance of Stein" in Continuum, 4 (Summer 1966), 197-207. Also in Response,1 (1967), 4-8, 32-34 and Search, 9:9 (gennaio 1967), 344-350.

Person in the World: Introduction to the Philosophy of Edith Stein (Boston: Kluwer Academic Publishers, 1997).

Review of Stein's Edith Steins Werke V and I in New Scholasticism, 37 (1963), 94-97.

\section{Baseheart, M.C., Linda Lopez McAlister, \& Waltraut Stein}

"Edith Stein" in A History of Women Philosophers, Vol. 4 ed. Ellen Waithe (The Hague: Martinus Nijhoff, 1990 \& Boston: Kluwer, 1995), 157-187. 


\section{Bauks, Bernard}

"Edith Stein's phenomenological approach to the meaning of 'night' in the writings of St. John of the Cross as found in The Spiritual Canticle of the Cross" (Thesis, Holy Cross Abbey, May 1975)

\section{Beckmann, Beate [Beate Beckmann-Zoller]}

"Edith Stein's Theory of the Person in her Münster Years (19321933)," trans. Amalie Enns, in American Catholic Philosophical Quarterly, 82:1 (Winter 2008), 47-70.

\section{Berkman, Joyce A.}

"Edith Stein: a life veiled and unveiled" in American Catholic Philosophical Quarterly, 82:1 (Winter 2008), 5-30.

(ed). Contemplating Edith Stein (Notre Dame, IN: University of Notre Dame Press, 2006).

"Edith Stein: A Life Unveiled and Veiled" in special edition of American Catholic Philosophical Quarterly 82:1 (Winter 2008), 5-29.

"The German-Jewish symbiosis in flux: Edith Stein's complex national/ethnic identity" in Contemplating Edith Stein ed. J.A. Berkman (Notre Dame, Ind: University of Notre Dame Press, 2006), 170-199.

"II am Myself It': comparative national identity formation in the lives of Vera Brittain and Edith Stein" in Women's History Review, 6:1 (1997), 47-73.

"The intellectual passion of Edith Stein: a biological profile" in Contemplating Edith Stein ed. J.A. Berkman (Notre Dame, Ind: University of Notre Dame Press, 2006), 15-47.

\section{Bodrato, Chiara}

"Man and democracy in the thoughts of Edith Stein" (trans. Cabiria Nardiollo) in Osservatore Romano (Sunday, Aug. 3, 1986).

\section{Borden Sharkey, Sarah [Sarah Borden]}

An Issue in Edith Stein's Philosophy of the Person: The Relation of Individual and Universal Form in Endliches und ewiges Sein (Ph.D. dissertation, Philosophy, Fordham University, 2001).

Edith Stein [Outstanding Christian Thinkers] (New York: Continuum, 2003). 
"Edith Stein and Individual Forms: A Few Distinctions regarding Being an Individual" in Yearbook of the Irish Philosophical Society, 2006, ed. Catherine Kavanagh Maynooth, 49-69.

"Edith Stein and John Paul II on Women" in Karol Wojtyla's Philosophical Legacy, ed. Nancy Mardas Billias, Agnes B. Curry, \& George F. McLean (Washington, DC: The Council for Research in Values in Philosophy, 2008), 265-276.

"Edith Stein and Thomas Aquinas on Being and Essence" in a special edition of American Catholic Philosophical Quarterly, 82:1 (Winter 2008), 87-104.

"Edith Stein's Understanding of Woman" in International Philosophical Quarterly 46:2 (June 2006), 171-190.

Foreword of Maybelle Padua's Contemplating Woman in the Philosophy of Edith Stein (Far Eastern University Press, 2007), xiiixxiii.

Introduction to Edith Stein's "The Interiority of the Soul" for a Reconsiderations piece in Logos: A Journal of Catholic Thought and Culture 8:2 (Spring 2005), 178-182.

"Review of Literature in English on Edith Stein" in Contemplating Edith Stein, ed. Joyce Berkman (Notre Dame: University of Notre Dame Press, 2006), 320-342.

Thine Own Self: Individuality in Edith Stein's Later Writings

(Catholic University of America Press, forthcoming 2009).

"What makes You You?: Edith Stein on Individual Form" in Contemplating Edith Stein, ed. Joyce Berkman (Notre Dame: University of Notre Dame Press, 2006), 283-300.

\section{Braybrooke, Neville}

"The Called and the Chosen: a Comparative Study of Edith Stein and Simone Weil" in Religion in Life, 28:1 (Winter 1958-1959), 98103. See also Doctrine and Life, 8 (July 1958), 120-125.

"Edith Stein and Simone Weil" in Hibbert Journal Quarterly for Religion, Pbilosophy and Theology, 253 (1965-1966), 75-80.

"Edith Stein and Simone Weil" in Vox Theologica: Interacademiaal Theologisch Tijdschrift, 29:3 (Januari 1959), 65-69.

"Edith Stein and Simone Weil: Spiritual Heroes of Our Times" in American Ecclesiastical Review, 163 (November 1970), 327-333. 
"Edith Stein and Simone Weil: A Study in Belief" in Spiritual Life, 14 (Winter 1968), 241-247.

\section{Brennan, Mary Anne}

"Bibliography" in Arthur Giron's Edith Stein: A Dramaturgical Sourcebook ed. Donald Marinelli (Pittsburgh, PA: Carnegie Mellon UP, 1994), 179-210.

\section{Brenner, Rachel Feldhay}

Writing as Resistance: Four Women Confronting the Holocaust, Edith Stein, Simone Weil, Anne Frank, Etty Hillesum (University Park: Pennsylvania State University Press, 1997 \& 2003).

\section{Calcagno, Antonio}

"Assistant and/or collaborator? Edith Stein's relationship to Edmund Husserl's Ideen II" in Contemplating Edith Stein ed. J.A. Berkman (Notre Dame, Ind: University of Notre Dame Press, 2006), 243-270.

(ed). "Edith Stein," special edition of American Catholic Philosophical Quarterly 82:1 (Winter 2008).

"Editor's Introduction" in special edition of American Catholic Philosophical Quarterly 82:1 (Winter 2008), 1-3

"Die Fülle oder das Nichts? Edith Stein and Martin Heidegger on the question of Being" in American Catholic Philosophical Quarterly, LXXIV: 2 (2000), 269-285.

'Edith Stein: Is the State responsible for the Immortal Soul of the Person?' in Logos 5:1 (Winter, 2002).

"God and the caducity of Being: Jean-Luc Marion and Edith Stein on thinking God",

<http://www.bu.edu/wcp/Papers/Reli/ReliCalc.htm>.

"Persona Politica: Unity and Difference in Edith Stein's Political Philosophy" in International Philosophical Quarterly, 37:2 (1997), 203215.

The Philosophy of Edith Stein (Pittsburgh, PA: Duquesne University Press, 2007).

"Thinking Community and the State from Within" in special edition of American Catholic Philosophical Quarterly 82:1 (Winter 2008), 31-45. 


\section{Chastain, Melissa}

Edith Stein: The Rhetoric of Responsibility_(Doctoral dissertation, Communications, Duquesne University, 2007).

\section{Collins, James}

"Edith Stein and the Advance of Phenomenology" in Thought, 17

(December 1942), 685- 708.

"Edith Stein as a Phenomenologist" in Three Paths in Philosophy (Chicago: Henry Regnery Co., 1962 \& 1982), 85-105. Reprinted and expanded in 1969 as Crossroads in Philosophy.

\section{Conn, Joann Wolski}

"Edith Stein and Authentic Feminism" [review of Essays on Woman] in Cross Currents, 28 (1988), 223-226

\section{Dolling, Lisa M.}

"Edith Stein's philosophy of "liberal education"' in Contemplating Edith Stein ed. J.A. Berkman (Notre Dame, Ind : University of Notre Dame Press, 2006), 226-241.

\section{Donohue, John W.}

"Edith Stein: A Self-Portrait" in America, 171 (December 10, 1994), 23-26.

"Edith Stein, Saint" in America, 176 (June 21, 1997), 8-9.

"Edith Stein, santa" in Mensaja [Santiago de Chile], 47:473 (1998), 10-12.

"Edith Stein's Early Years" (review of Stein's Life in a Jewish Family) in America (January 3, 1987), 7-9, 19.

"Time for Edith Stein" in America, 148 (February 26, 1983), 145149.

\section{Donovan, Victor}

"Edith Stein" in The Sword [Washington], 22 (1962), 159-164.

"Edith Stein and the Cross" in Blessed by the Cross: Five Portraits of Edith Stein ed. James A. Sullivan (New Rochelle, NY: Catholics United for the Faith, 1990).

"Edith Stein and the Edith Stein Guild" in Never Forget. Christian 
and Jewish Perspectives on Edith Stein ed. Waltraud Herbstrith (Washington, DC: ICS Publications, 1998), 177-183.

\title{
Duran, Jane
}

Eight women philosophers: theory, politics, and feminism (Urbana: University of Illinois Press, 2006)

\section{Feist, Richard and Sweet, William, eds.}

Husserl and Stein (Washington, DC: Council for Research in Values and Philosophy, 2003).

\section{Gantt, Edwin E.}

Struggling to empathize: a theoretical reflection on the meaning of buman empathy (emotional contagion) (Doctoral dissertation, Duquesne University, 1998).

\author{
*Garcia, Laura
}

"The Primacy of Persons: Edith Stein and Pope John Paul II" in Logos: A Journal of Catholic Thought and Culture, 1:2 (Summer 1997), 90-99.

\section{Gardner, William T.}

"Arthur Giron and Edith Stein" in Arthur Giron's Edith Stein: A Dramaturgical Sourcebook ed. Donald Marinelli (Pittsburg, PA: Carnegie Mellon UP, 1994), 25-30.

\section{Greene, Dana K.}

"In search of Edith Stein: beyond hagiography" in Contemplating Edith Stein ed. J.A. Berkman (Notre Dame, Ind: University of Notre Dame Press, 2006), 48-58.

\section{Gurmin, J. Haydn}

"Edith Stein and Tania Singer: A Comparison of Phenomenological and Neurological Approaches to the 'Problem of Empathy"' in Maynooth Philosophical Papers 4 (2007), 99-122.

\section{Haney, Kathleen}

"Edith Stein" in Encyclopedia of Phenomenology ed. Lester Embree, Elizabeth A. Behnke, David Carr, et. al. (Boston: Kluwer, 1997), 679-683.

"Edith Stein: Woman and Essence" in Feminist 
Phenomenology ed. Linda Fisher \& Lester E. Embree (Boston, Dordrecht: Kluwer, 2000), 213-235.

"Edith Stein: Woman as Ethical Type" in Phenomenological Approaches to Moral Philosophy ed. John Drummond (Dordrecht: Kluwer, 2002), 451-473.

"Empathy and Ethics" in Southwest Philosophy Review, 10:1 (1994), 57-65.

"Empathy Revisited" in The Philosophy of Edith Stein: The Eighteenth Annual Symposium of the Simon Silverman Phenomenology Center (Pittsburgh: Silverman Institute for Phenomenology at Duquesne University, 2001), 18-33.

\section{Haney, Kathleen $\mathbf{M}$ and Johanna Valiquette}

"Edith Stein: Woman As Ethical Type" in Phenomenological Approaches to Moral Philosophy, ed. John Drummond (Dordrecht: Kluwer Academic Pub, 2002), 451-473.

\section{Hart, James G.}

"Contingency of Temporality and Eternal Being: a Study of Edith Stein's Phenomenological Theology as it appears primarily in Endliches und Ewiges Sein" in The Philosophy of Edith Stein: The Eighteenth Annual Symposium of the Simon Silverman Phenomenology Center (Pittsburgh: Silverman Institute for Phenomenology at Duquesne University, 2001), 34-68.

"Notes on Temporality, Contingency, and Eternal Being: Aspects of Edith Stein's Phenomenological Theology" in Edith Stein. Themen, Berüge, Dokumente ed. Beate Beckmann and Hanna-Barbara Gerl-Falkovitz (Würzburg: Königshausen \& Neumann, 2002), 97-106.

\section{Healy, John}

"Empathy with the Cross: A Phenomenological Approach to the "Dark Night"' in Essays in Honor of Joseph P. Brennan ed. R. McNamara (Rochester, NY: The Seminary, 1976 \& 1977), 21-35.

\section{Hughes, J.}

"Edith Stein's Doctoral Thesis on Empathy and the Philosophical Climate From Which It Emerged" in Teresianum, 36 (1985), 455- 484. 
"Edith Stein's Doctoral Thesis on Empathy" in Mount Carmel, 36 (1987), 121-144.

\section{Ibana, Rainier}

"The Stratification of Emotional Life and the Problem of Other Minds According to Max Scheler" in International Philosophical Quarterly (1991), 461-471

\section{Ingarden, Roman}

"Edith Stein on her Activity as an Assistant of Edmund Husserl," trans. Janina Makota, in Philosophy and Phenomenological Research, 23 (1962), 155-175.

\section{Kaufmann, Fritz}

Review of Edith Steins Werke II in Philosophy and Phenomenological Research, 12 (1952), 572- 577.

\section{Kovacs, George}

"The way to ultimate meaning in Edith Stein's phenomenology" in Ultimate Reality and Meaning, 26:4 (D 2003), 263-282.

Layug, Jose A. E. L.

St. Edith Stein's concept of man: an inquiry in the light of fides et ratio (Master's Thesis, Immaculate Conception Major Seminary, Guiguinto, Bulacan, 2003).

\section{Leask, Ian}

"Edith Stein and others" in Journal of the British Society for Phenomenology, 33:3 (October 2002), 286-298.

"Flesh, Chiasm...Providence?" in Journal of the British Society for Phenomenology, 37:1 (January 2006), 5-20.

\section{Lebech, A. Mette}

"Edith Stein's philosophy of education in The structure of the human person" in Religion, Education, and the Arts, Issue V: the philosophy of education, 5 (2005), 55-70.

On the Problem of Human Dignity: A Hermeneutical and Phenomenological Investigation, (Würzburg, Verlag Königshausen \& Neumann, 2009) 
'Stein's Phenomenology of the Body. The Constitution of the Human Being between Description of Experience and Social Construction', in Yearbook of the Irish Philosophical Society 2008, ed. Fiachra Long, forthcoming 2009

'Stein's Phenomenology of the Body. The Constitution of the Human Being between Description of Experience and Social Construction' (shorter version), in Maynooth Philosophical Papers 2008, ed. Simon Nolan, forthcoming 2009

"Study Guide to Edith Stein's Philosophy of Psychology and the Humanities" in Yearbook of the Irish Philosophical Society: Voices of Irish Philosophy 2004, (2004), 40-76.

The identification of buman dignity (Doctoral thesis, Philosophy, Katholieke Universiteit Leuven, Hoger Instituut voor Wijsbegeerte, 2005).

Why does John Paul II refer to Edith Stein in Fides et Ratio?' in The Challenge of Truth, ed. by J. McEvoy (Veritas, Dublin, 2000)

Leggett, Rosalind M.

Edith Stein, her life and times, with special reference to empatby in women (M.A. Thesis, California State University, Dominguez Hills, 2004).

MacIntyre, Alasdair

Edith Stein: A Philosophical Prologue, 1913-1922 (Lanham, MD: Rowman \& Littlefield Publishers, 2006).

\section{Madden, Nicholas}

"Edith Stein on the symbolic theology of Dionysius the Areopagite" in Irish Theological Quarterly, 71 (2006), 29-45.

Maliakkal, Varghese

Self-transcendence through relation in the philosophical anthropology of Edith Stein (Romae: Pontificia Università lateranense, 2003).

\section{Marinelli, Donald (ed.)}

Arthur Giron's Edith Stein: A Dramaturgical Sourcebook (Pittsburgh, PA: Carnegie Mellon University Press, 1994). 
Martino, Daniel J. (ed.)

The Eighteenth Annual Symposium of the Simon Silverman Phenomenology Center. The Philosophy of Edith Stein (Duquesne University, Simon Silverman Phenomenology Center, 2001).

\section{Maskulak, Marian A.}

Edith Stein and the body-soul-spirit at the Center of Holistic Formation (New York: Peter Lang, 2007).

Reclaiming the soul: Edith Stein and the unity of the body-soulspirit at the center of holistic formation (Doctoral dissertation, University of St. Michael's College (Canada), 2005, published, Ottawa: Library and Archives Canada Bibliothèque et Archives Canada, 2006).

\section{McAlister, Linda Lopez}

"Edith Stein: Essential Differences" in Philosophy Today, 37 (Spring 1993), 70-77. See also "Edith Stein: essential differences" in Contemplating Edith Stein ed. J.A. Berkman (Notre Dame, Ind: University of Notre Dame Press, 2006), 201-211.

"Feminist Saint?: Edith Stein's Feminism" in Florida International University's Occasional Papers in Women's Studies series, 1989.

\section{McCullough, Ernest J.}

"Edith Stein and intersubjectivity" in Husserl and Stein, ed. Richard Feist and William Sweet (Washington, DC: Council for Research in Values and Philosophy, 2003),

\section{McInerny, Ralph}

"Edith Stein and the Perennial Philosophy" in Blessed by the Cross: Five Portraits of Edith Stein ed. James A. Sullivan (New Rochelle, NY: Catholics United for the Faith, 1990), 13-15.

"Edith Stein and Thomism" in Edith Stein Symposium [Carmelite Studies 4] ed. John Sullivan (Washington DC: ICS Publications, 1987), 74-87. 
"Roses only live one morn": a phenomenological analysis of the autobiographies of Edith Stein and Titus Brandsma (MA Thesis, Catholic University of America).

Miles, Judy A.

\section{Moran, Dermot}

Simone de Beauvoir and Edith Stein: a philosophical analysis of feminism (Doctoral dissertation, Claremont Graduate School, 1991).

"Other bodies and other minds in Edith Stein: or, how to talk about empathy" in Husserl and Stein Eds. Richard Feist and William Sweet (Washington, DC: Council for

"Immanence, Self-Experience, and Transcendence in Edmund Husserl, Edith Stein, and Karl Jaspers" in American Catholic Philosophical Quarterly 82:2 (Spring 2008), 265-291.

"The Problem of Empathy: Lipps, Scheler, Husserl and Stein" in Amor amicitiae: On the Love That Is Friendship: Essays in Medieval Thought and Beyond in Honor of the Rev. Professor James McEvoy (Bibliotheca 6), ed Thomas A. F. Kelly (Leuven: Peeters, 2004), 269-312.

Nota, John [Jan] H.

"Edith Stein and Martin Heidegger" in Edith Stein Symposium [Carmelite Studies 4] ed. John Sullivan (Washington DC: ICS Publications, 1987), 50-73.

"Misunderstanding and Insight About Edith Stein's Philosophy" in Human Studies, 10 (1987), 205-212.

Oldfelt, Christina Kerstin

Aspects of the religious experience of Edith Stein as seen from a perspective of analytical psychology (Diploma thesis, C.G. Jung Institute, Zurich, 1990)

\section{Parsons, Judith Kathryn}

Edith Stein: toward an ethic of relationship and responsibility (Doctoral dissertation, Duquesne University, 2005). 
Parviainen, Jaana

"Kinaesthetic Empathy" in Source: Dialogue and Universalism, 13:(11-12) (2003), 151-162

Payne, Steven

"Edith Stein: A Fragmented Life" in America, 179:10 (October 10, 1998), 11-14. See also http://www.americapress.org/articles/Payne.htm.

"Edith Stein and John of the Cross" in Teresianum, 50:I-II (19991), 239-256.

Phelim, Fr.

Edith Stein in her Writings (Galway: Carmelite Publications, n.d.).

Puthenpurackal, John J.

"The Irreconciliability of Thomism and Phenomenology: Thinking Beyond Edith Stein" in The Living Word [Alwaye], 93 (1987), 253-274.

\section{Quito, Emerita}

Phenomenology: Edmund Husserl and Edith Stein (Malate, Manila, Philippines: De La Salle University Press, 2001).

Read, Denis

"St. Edith Stein: the prophetic philosopher for the new millennium",

$<$ http://showcase.netins.net/web/solitude/stein.html>.

\section{Redmond, Walter}

"A Nothing that Is: Edith Stein on Being without Essence" in a special edition of American Catholic Philosophical Quarterly, 82:1 (Winter 2008), 71-86.

\section{Sawicki, Marianne}

Body, Text and Science: the Literacy of Investigative Practices and the Phenomenology of Edith Stein (Doctoral dissertation, University of Kentucky, 1996, published, Boston: Kluwer Academic Press, 1997). 
"Chronology of Writings of Edith Stein" at http://www.husserlpage.com/hus_r2st.html. Accessed July 11, 2008.

"Edith Stein's Critique of Hume's Association Theory" in Yearbook of the Irish Philosophical Society: Voices of Irish Philosophy 2004, (Maynooth, 2004), 138-147.

"Edith Stein's Philosophy of Psychology and the Humanities: The Jahrbuch Treatises of 1922" in The Philosophy of Edith Stein: The Eighteenth Annual Symposium of the Simon Silverman Phenomenology Center (Pittsburgh: Silverman Institute for Phenomenology at Duquesne University, 2001), 69-95.

"Empathy Before and After Husserl" in Philosophy Today, 22 (1997), 123-127.

"Husserl and Stein on the State: Toward a Critique of Race Theory" at www.nd.edu/ msawicki/STAAT.htm.

'Making-Up-Husserl's Mind about Constitution' in Yearbook of Irish Philosophical Society 2007: (Maynooth, 2007), 191-216

"Personal Connections: The Phenomenology of Edith Stein" in Yearbook of the Irish Philosophical Society: Voices of Irish Philosophy 2004, (Maynooth, 2004), 148-169.

"The Humane Community: Husserl versus Stein" in Husserl and Stein ed. Richard Feist \& William Sweet (Washington, DC: Council for Research in Values and Philosophy, 2003), 141-154

\section{Schudt, Karl}

"Edith Stein's proof for the existence of God from consciousness" in a special edition of American Catholic Philosophical Quarterly, 82:1 (Winter 2008), 105-126.

Faith and Reason in the Philosophy of Edith Stein (Ph.D. dissertation, Marquette University, 2001).

"Faith and reason in the philosophy of Edith Stein" in Faith and Reason, 27:2-4 (Summer-Winter, 2002), 295- 326.

\section{Secretan, Philibert}

"The Self and the Other in the Thought of Edith Stein" in The Self and the Other: The Irreducible Element in Man, I 
[Analecta Husserliana 6] (Dordrecht, Holland: D. Reidel, 1977), 87-98.

\section{Spiegelberg, Herbert}

"Edith Stein" in The Phenomenological Movement: A Historical Introduction: Vol. 1 (The Hague: Martinus Nijhoff, 1960 \& 1982).

\section{Stein, Waltraut J.}

"Edith Stein" in Resources for Feminine Research, 16 (Summer 1987), 54-55.

\section{Sullivan, John}

Review of Edith Stein: Selected Writings with Comments, Reminiscences and Translations of Her Prayers and Poems in Spiritual Life, 37 (1991), 241-243.

Sweeney, Meghan T.

A performance of being and the enacting texts of Edith Stein (Doctoral dissertation, Emory University, 2006).

\section{Sweet, William and Feist, Richard}

"Introduction: Husserl, Stein, and Phenomenology" in Husserl and Stein Eds. Richard Feist and William Sweet (Washington, DC: Council for Research in Values and Philosophy, 2003)

\section{Van den Berg, Regina}

Community in the Thought of Edith Stein (Ph.D. dissertation, Catholic University of America, 2000).

Verbillion, June M.

A critical analysis of the educational theories of Edith Stein (Doctoral dissertation, Loyola University of Chicago, 1960).

Wilk, Kazimierz Rafal 'On Human Being: A Dispute between Edith Stein and Martin Heidegger’ in Logos 10:4 (Fall, 2007).

\section{Wobbe, Theresa}

"The complex modernity of Edith Stein: new gender relations and options for women in the early-twentiethcentury Germany" in Contemplating Edith Stein ed. J.A. 
Berkman (Notre Dame, Ind: University of Notre Dame Press, 2006), 122-133.

Wos, J.

"Dispute over the truth of existence. Letters from Edith Stein to Roman Ingarden" in Aevum. Rassegna di scienze storiche, linguistiche e filologiche, 73:3 (Sep.-Dec. 1999), 964965.

\section{Wright, Terrence C.}

"Artistic Truth and the True Self in Edith Stein" in American Catholic Philosophical Quarterly, 82:1 (Winter 2008), 127-142.

"Edith Stein: Prayer and Interiority" in The Phenomenology of Prayer ed. Bruce Benson \& Norman Wirzba (Bronx, NY: Fordham University Press, 2005), 134-141.

'Phenomenology and Moral Imagination', Logos 6:4 (Fall, 2003). 